\title{
IN VITRO EFFICACY OF MYCOTOXINS' ADSORPTION BY NATURAL MINERAL ADSORBENTS
}

\author{
A. Bočarov-Stančić ${ }^{1}$, M. Adamović ${ }^{2}$, N. Salma ${ }^{1}$, M. Bodroža-Solarov ${ }^{3}$, J. \\ Vučković ${ }^{3}$, V. Pantić ${ }^{1}$ \\ ${ }^{1}$ Bio-Ecological Centre DOO, 23000 Zrenjanin, Republic of Serbia \\ ${ }^{2}$ Institute for Technology of Nuclear and Other Mineral Raw Materials, 11000 Belgrade, Republic of \\ Serbia \\ ${ }^{3}$ Institute for Food Technology, 21000 Novi Sad, Republic of Serbia \\ Corresponding author: naukabec@bioec.rs \\ Original scientific paper
}

Abstract: The paper describes in vitro model for evaluation of natural mineral adsorbents ability to adsorb mycotoxins. Bentonite, diatomite and zeolite were prepared in the Institute for Technology of Nuclear and Other Mineral Raw Materials, Belgrade. A total of six mycotoxins: aflatoxin B1 (AFL), ochratoxin A (OTA), deoxynivalenol (DON), zearalenone (ZON), diacetoxyscirpenol (DAS) and T-2 toxin were tested in vitro. For adsorption experiments crude extracts of mycotoxins, produced in the Department of Microbiology of Bio-ecological Center in Zrenjanin, were used. The ability for binding mycotoxins was evaluated in the electrolyte $0.1 \mathrm{M} \mathrm{K}_{2} \mathrm{HPO}_{4}$ which $\mathrm{pH}$ value was adjusted to 3.0 and 6.9, respectively. Mass ratio of individual mycotoxin and natural mineral adsorbent was 1:5000. The experimental mixtures were incubated for 1 hour on a rotary shaker $(185 \mathrm{rpm})$ at room temperature $\left(22-25^{\circ} \mathrm{C}\right)$. After incubation the extractions of unadsorbed mycotoxins from the filtrates were performed with organic solvents, and their quantifications were done by thin-layer chromatography (TLC). By the use of TLC method it was noted that bentonite, diatomite and zeolite binded more than $95 \%$ of applicated AFL. In the case of OTA only diatomite adsorbed that toxin - adsorption index was $66.67 \%$. Binding of DON has been observed only at pH 3.0 of electrolyte. Its adsorption index varied from 25.00 to $50.00 \%$ depending on the type of mineral adsorbent. Effect of electrolyte $\mathrm{pH}$ value on the binding of ZON was not so expressed. Its adsorption index ranged from 12.20 to $37.00 \%$. In the case of type A trichothecenes (DAS and T-2 toxin) bentonite, diatomite, and zeolite binded only T-2 toxin. The amount of adsorbed T-2 toxin ranged from 16.66 to $33.33 \%$. The obtained results point out the need for activation or processing of natural mineral adsorbens, especially bentonite and zeolite, in order to increase the efficiency of adsorption of the wider spectrum of mycotoxins.

Key words: mycotoxins, mineral adsorbents, in vitro 


\section{Introduction}

Considerable investigations had been undertaken at finding methods for prevention of toxic effects of mycotoxins. One approach includes detoxification and inactivation of these fungal metabolites by the use of mycotoxin binders. The aim of these non nutritive additives is to inhibit the uptake of mycotoxins by an animal in vivo. These adsorbent materials are intended to act as "chemical sponges" that bound mycotoxins in gastrointestinal tract thus preventing the uptake and subsequent distribution to target animal organs. The efficacy of adsorption process is depending on the chemical structure of binding agent and the mycotoxin, respectively. The most important characteristics for adsorption is the physical structure of the adsorbent (the size of pores, accessibility of surface area, total charge and charge distribution) and properties of adsorbed mycotoxin (polarity, solubility, shape and charge distribution) (Kollosova et al., 2009). Various natural materials had the potential to bind mycotoxins in feed.

Bentonite (BEN) is a hydrated aluminum silicate of volcanic origin. It consists of minerals from the smectite group, mostly of montmorillonite (50-90\%); hectorite, saponit, beidelit and nontronit may also be present. The crystal structure of this mineral adsorbent is built of $\mathrm{SiO}_{2}$ tetrahedrons and $\mathrm{Al}_{2} \mathrm{O}_{3}$ octahedrons, which are interconnected and build a three-layer plates with a negative charge, while the edges of the lamellae have positive charge. BEN contains interchangeable cations $\mathrm{Na}, \mathrm{K}, \mathrm{Ca}, \mathrm{Mg}$. In the presence of water lamellae are separated and volume is increased. In feed industry BEN is used in the pelleting process of feed mixtures. This mineral adsorbent increases the hardness and strength of pellets. It adsorbs some mycotoxins. Particularly is pronounced BEN's affinity towards aflatoxins (90-95\%) and less for zearalenone and ochratoxin (Huwig et al., 2001). Besides mycotoxins it binds and radionuclides, toxic metals and ammonia (Adamović et al., 2009). Positive effects of pelleting and sodium bentonite utilisation in concentrate mixtures on cattle performances was shown by Stojanović et al. (2008).

Diatomite (DIA) is a sediment formed in lacustrine and marine environments. It is composed of very small (from 0.01 to $0.4 \mathrm{~mm}$ ) shells of silicon, unicellular algae (Diatomeae), whose number amounts to 10-30 millions in $\mathrm{cm}^{3}$. In addition, these deposits contain the remains of sponges, Radiolaria, admixtures of clay, quartz etc. DIA has a small mass $\left(0.5-0.8 \mathrm{~g} / \mathrm{cm}^{3}\right)$ and high porosity. Due to the high content of silicon dioxide this mineral adsorbent has a large porosity, and thanks to that the high adsorption capacity. Among other things, DIA is used as a component for the production of certain mycotoxin adsorbents and for remediation of diarrhea in animals (Whitlow, 2006; Živkovic et al. 2006).

Zeolite (ZEO) is a hydrated aluminosilicate of alkaline and alkaline earth metal ions, which possess an infinite three-dimensional crystal structure. Its main 
ingredient is a mineral clinoptilolite (60-90\%). ZEO is characterized by its ability to lose or receive water and change cations without major changes in the structure. Basic building unit of zeolite structure is a tetrahedron in whose center is an atom of silicon or aluminum, and at the top of tetrahedron there are oxygen atoms that are shared by two tetrahedra. Because of this mineral is rich in channels and cavities in one, two or three directions. Size of channels determine the possibility of sorption of different molecules. The cations placed in channels can be replaced with other metal ions. On that fact is based the ability of ZEO to, with greater or lesser success, adsorb specific mycotoxins on its negative charged surface (Tomašević-Čanović et al. 2001). Besides that this mineral adsorbent can bind also radionuclides, toxic metals and ammonia (Adamović et al., 2003; Vićentijević et al., 2006) and its addittion has significant influence on all chemical parametrers of chemical composition and biochemical changes in whole maize plant silages (Đorđević et al., 2006).

\section{Materials and Methods}

Mineral adsorbents. Bentonite was obtained from the site Šipovo, Republic of Bosnia and Herzegovina. Tested sample of diatomite originated from diatomite mine Kolubara - Lazarevac, location Baroševac, field "B", while zeolite was obtained from site Igroš, Kopaonik, Republic of Serbia. Samples of BEN and ZEO were prepared in semi-industrial conditions, while DIA in the laboratory conditions (the separation of impurities and grinding, without pretreatment) in the Institute for Technology of Nuclear and Other Mineral Raw Materials, Belgrade. Chemical composition of mineral adsorbents was determined by AAS Analyst device 300, and granulometric composition by Cyclosizer DM 10-0/44 device.

Production, quantification and isolation of mycotoxins. Aflatoxin B1 (AFL), ochratoxin A (OTA), deoxynivalenol (DON) and zearalenone (ZON) were produced employing solid state fermentation as per the methods of BočarovStančić et al. (2009a), Bočarov-Stančić et al. (2010) and Bočarov-Stančić et al. (2009b), respectively. Type A trichothecenes (diacetoxyscirpenol - DAS and T-2 toxin) were biosynthesized by submerged fermentation in liquid medium (BočarovStančić et al., 2007). The respective fungal cultures used were: Aspergillus flavus GD-2 (leg. prof. dr G. Dimić, Technological Faculty, Novi Sad, R. Serbia), $A$. ochraceus CBS 108.08, Fusarium graminearum GZ-LES (leg. prof. dr J. Lević, Maize research institute, Belgrade-Zemun, R. Serbia), F. graminearum D2 (leg. dr A. Bočarov-Stančić, Bio-Ecological Centre, Zrenjanin, R. Serbia), F. semitectum SL-B (leg. dr A. Bočarov-Stančić, Bio-Ecological Centre, Zrenjanin, R. Serbia), and F. sporotrichioides ITM-391 (leg. dr A. Bottalico, Consiglio Nazionalle delle Richerce, Istituto Tossine a Micotossine da Parassiti Vegetali, Bari, Italy). 
Isolations of mycotoxins and determinations of single mycotoxin content in solid substrates were done according to standard thin-layer chromatographic method for fodder analysis (The Official Gazete of SFRJ, issue 15/87). Isolations of type A trichothecenes were done by ethyl acetate and their quantities were determined by thin-layer chromatographic (TLC) method according to Rukmini and Bhat (1978). Isolated crude toxins were evaporated to dryness and dissolved in following solvents: ethanol (AFL, OTA, ZON), ethyl acetate (DAS, T-2) and methanol (DON). The final concentrations of stock mycotoxins' solutions were 0.1 $\mu \mathrm{g} / \mu \mathrm{l}(\mathrm{AFL})$ and $1 \mu \mathrm{g} / \mu \mathrm{l}$ (OTA, DON, ZON, DAS and T-2), respectively.

Experimental procedure. For adsorption experiments stock solution of AFL was diluted to $0.2 \mu \mathrm{g} / \mathrm{ml}$, of ZON to $0.8 \mu \mathrm{g} / \mathrm{ml}$, and of all other mycotoxins to $2.0 \mu \mathrm{g} / \mathrm{ml}$ with electrolyte $\left(0.1 \mathrm{M} \mathrm{K}_{2} \mathrm{HPO}_{4}\right)$. $\mathrm{pH}$ value of electrolyte was adjusted with $0.1 \mathrm{M} \mathrm{HCl}$ or $0.1 \mathrm{NaOH}$ to 3.0 and 6.9 , respectively.The in vitro binding ability of BEN, DIA and ZEO was tested as follows: aliquots $(50 \mathrm{ml})$ of test solutions were added to Erlenmayer flasks $(250 \mathrm{ml})$ containing $500 \mathrm{mg}$ of single adsorbent in the case of OTA, DON, DAS and T-2 toxin, $200 \mathrm{mg}$ in the case of $\mathrm{ZON}$, and $50 \mathrm{mg}$ in the case of AFL. Controls were prepared by adding of $50 \mathrm{ml}$ of test solutions without mineral adsorbent. The flasks were stoppered, incubated for 1 hour on rotary sheaker $(185 \mathrm{rpm})$ at room temperature $\left(22-25{ }^{\circ} \mathrm{C}\right)$ and then filtered. Mycotoxins' concentrations in $25 \mathrm{ml}$ aliquots of electrolyte with adsorbent (C) and without it $\left(\mathrm{C}_{\mathrm{o}}\right)$ were determined after extraction with $2 \times 15 \mathrm{ml}$ of organic solvents: benzene (ZON), benzene-acetonitrile (AFL), and ethyl acetate (OTA, DON, DAS and T-2) respectively by TLC methods (The Official Gazette of SFRJ, issue 15/87; Rukmini and Bhat, 1978). All analysis were were performed in three replications. The adsorption index of individual mycotoxin in percentages was calculated by the following formula:

$$
\text { Adsorption index }=\left[\begin{array}{c}
C_{0}-C \\
C_{0}
\end{array}\right] x 100
$$

\section{Results and Discussion}

The chemical composition and cation exchange capacity (CEC) of the employed mineral adsorbents is presented in Table 1. All three used adsorbents had a high content of $\mathrm{SiO}_{2}$. (48.48 to $79.79 \%$ ). The highest content of $\mathrm{SiO}_{2}$ was found in DIA (derived from the shells of silicon unicellular Diatomeae algae) the adsorbent significantly different from the BEN and ZEO. On the other hand DIA had significantly lower content of other components, mainly $\mathrm{Al}_{2} \mathrm{O}_{3} \mathrm{CaO}$ and $\mathrm{MgO}$, and other cations, which has impacted on its' cation exchange capacity. 
Table 1. The chemical composition of mineral adsorbens

\begin{tabular}{|l|c|c|c|}
\hline Parameter (\%) & Bentonite & Diatomite & Zeolite \\
\hline $\mathrm{SiO}_{2}$, & 48.48 & 79.79 & 65.69 \\
\hline $\mathrm{Al}_{2} \mathrm{O}$ & 22.39 & 9.41 & 14.03 \\
\hline $\mathrm{CaO}$ & 5.86 & 0.63 & 3.57 \\
\hline $\mathrm{Fe}_{2} \mathrm{O}_{3}$, & 4.73 & 1.11 & 2.34 \\
\hline $\mathrm{MgO}$ & 1.71 & 0.14 & 1.09 \\
\hline $\mathrm{K}_{2} \mathrm{O}$ & 0.40 & 0.79 & 1.39 \\
\hline $\mathrm{Na}_{2} \mathrm{O}$ & 0.07 & 0.08 & 1.41 \\
\hline $\mathrm{TiO}_{2}$, & 0.34 & 0.21 & 0.17 \\
\hline Loss by ignition & 16.02 & 7.84 & 10.29 \\
\hline CEC mEq/100 & 141.23 & 42.75 & 142.24 \\
\hline
\end{tabular}

CEC: cation exhance capacity

Despite differences in chemical composition the common property of all investigated mineral adsorbents was their porosity, due to the existence of cavities and canals that spread in different directions, allowing them to exchange cations and thus to adsorb certain mycotoxins. The highest cation exchange capacity had ZEO (142.24 mEq/100 g), slightly lower BEN (14.23 mEq/100 g) and the lowest DIA (42.75 mEq/100 g).

Table 2. Grading composition of mineral adsorbents (particle size)

\begin{tabular}{|c|c|c|c|c|c|}
\hline \multicolumn{2}{|c|}{ Bentonite } & \multicolumn{2}{c|}{ Diatomite } & \multicolumn{2}{c|}{ Zeolite } \\
\hline $\begin{array}{c}\text { Diameter } \\
(\mu \mathrm{m})\end{array}$ & $\mathrm{M}(\%)$ & $\begin{array}{c}\text { Diameter } \\
(\mu \mathrm{m})\end{array}$ & $\mathrm{M}(\%)$ & $\begin{array}{c}\text { Diameter } \\
(\mu \mathrm{m})\end{array}$ & $\mathrm{M}(\%)$ \\
\hline $63-61$ & 12.60 & $63-48$ & 1.30 & $63-53$ & 3.50 \\
\hline $61-46$ & 2.0 & $48-36$ & 0.90 & $53-40$ & 6.80 \\
\hline $46-32$ & 3.50 & $36-25$ & 0.65 & $40-28$ & 11.83 \\
\hline $32-21$ & 2.70 & $25-16$ & 0.55 & $28-18$ & 13.63 \\
\hline $21-15$ & 3.50 & $16-12$ & 1.15 & $18-13$ & 15.20 \\
\hline$<15$ & 75.00 & $<12$ & 95.45 & $<13$ & 49.04 \\
\hline$\Sigma$ & 100.00 & $\sum$ & 100.00 & $\sum$ & 100.00 \\
\hline
\end{tabular}

$M=$ mass of particles in $\%$ in the specified size range

The particle size of tested adsorbents (100\%) was below $63 \mu \mathrm{m}$ (Table 2). Smallest particles were found in DIA - $95.45 \%$ of mass was below $12 \mu \mathrm{m}$. The BEN had $75.00 \%$ of particle mass below $15 \mu \mathrm{m}$, while ZEO had $49.04 \%$ f particle mass mass smaller than $13 \mu \mathrm{m}$. These data indicate that there exist, to some extent, the difference of distribution of particle sizes. In our following tests we are going to have in mind this detail and try to equalize the size of the particles of studied natural mineral adsorbents.

Aflatoxin B1. By the use of TLC method it was noted that the BEN, DIA and ZEO adsorbed more than $95 \%$ of applicated AFL (Table 3). Obtained result is 
not surprising because it is known that surface of alumosilicate adsorbens (BEN and ZEO) when saturated with water atract polar functional groups of AFL and other polar mycotoxins (Tomašević-Čanović et al., 2001; Kollosova et al., 2009). Unlike the results of Thimm et al. (2001) no influence of $\mathrm{pH}$ value of electrolyte on the binding of this mycotoxin was observed during present investigation.

Ochratoxin A. In the case of OTA only DIA adsorbed that toxin adsorption index was $66.67 \%$ at $\mathrm{pH} 3.0$ (Table 3). That most mineral adsorbents show higher adsorption indexes of OTA at $\mathrm{pH} 3.0$ than at $\mathrm{pH} 6.5$ was noted and by other authors (Thimm et al., 2001). According to literature data (Whitlow, 2006; Manafi et al., 2009), besides binding AFL and OTA, diatemaceous earth has the potential to adsorb in vitro and other mycotoxins ( $\mathrm{ZON}, \mathrm{T}-2$ toxin and sterigmatosystin).

Deoxynivalenol. Adsorption index of DON varied from 25.00 to $50.00 \%$ depending on the type of mineral adsorbent (Table 3). In vitro binding of this fusariotoxin was observed only at $\mathrm{pH}$ 3.0. Contrary to our results other authors (Döll et al., 2004; Sabater-Vilar et al., 2004) found that most of the commercialy available mineral adsorbents were not able to bind DON in a appriciable percentage, while activated carbon was the best adsobent of this mycotoxin.

Zearalenone. Effect of electrolyte $\mathrm{pH}$ value on the adsorption of $\mathrm{ZON}$ was not so expressed (Table 3). Binding capacity of this mycotoxin ranged from 12.20 to $37.00 \%$. And other investigators (Bueno et al., 2005) observed that bentonite can bind zearalenone to some extent, although $\mathrm{ZON}$ adsorption rates up to $100 \%$ have only been observed with organophylic bentonites (Dakovic et al., 2001; Thimm et al., 2001; Stojšić et al., 2004).

Diacetoxyscirpenol. In tested in vitro conditions, natural mineral adsorbents (BEN, DIA, and ZEO) did not bind DAS. That there is litle or no beneficial effect against this type A trichothecene also showed the results of other authors (Devegowda and Aravind, 2002).

Table 3. Adsorption indexes of tested natural mineral adsorbents at different pH values

\begin{tabular}{|l|c|c|c|c|c|c|c|}
\hline \multirow{2}{*}{ Adsorbent } & \multirow{2}{*}{$\mathrm{pH}$} & \multicolumn{6}{|c|}{ Adsorption index of individual mycotoxins (\%) } \\
\cline { 3 - 8 } & & AFL & OTA & DON & ZON & DAS & T-2 \\
\hline \multirow{2}{*}{ Bentonite } & 3.0 & 96.90 & 0 & 50.00 & 37.00 & 0 & 25.00 \\
\cline { 2 - 8 } & 6.9 & 96.90 & 0 & 0 & 25.00 & 0 & 33.33 \\
\hline \multirow{2}{*}{ Diatomite } & 3.0 & 95.00 & 66.67 & 25.00 & 25.00 & 0 & 33.33 \\
\cline { 2 - 8 } & 6.9 & 95.00 & 0 & 0 & 25.00 & 0 & 33.33 \\
\hline Zeolite & 3.0 & 95.50 & 0 & 50.00 & 12.20 & 0 & 0 \\
\cline { 2 - 8 } & 6.9 & 95.50 & 0 & 0 & 12.20 & 0 & 16.7 \\
\hline
\end{tabular}


T-2 toxin. The amount of adsorbed T-2 toxin ranged from 16.66 to $33.33 \%$ (Table 3). With the exception of DIA, higher mycotoxin adsorption indexes were recorded at $\mathrm{pH} 6.9$ of tested electrolyte. Simirar in vitro binding capacties were observed with commercial adsorbents - 33.3\% Minazel and 31.3\% Minazel Plus (Bočarov-Stančić et al., 2000a i b; Nešić et al., 2007). In the case of three natural mineral adsorbents Stojanovic et al. (2008) found that hectorite showed much higher adsorption index (95\%) then BEN i ZEO.

In vivo experiments of Carson and Smith (1983) showed that 5\% bentonite added to diet of laboratory animals most successfully overcame growth depression and feed refusal caused by T-2 toxin. Results of Jacević et al. (2007) indicated that immune protection, in addition to previously established gut- and hepatic protection, significantly contributed to successful application against T-2 toxin sub acute intoxication in laboratory rats.

\section{Conclusion}

All tested mineral adsorbents showed the highest adsorption index in vitro for aflatoxin B1 (95.50-96.90\%).

Only diatomite was efficient in binding ochratoxin A (66.67\% at $\mathrm{pH} 3.0)$.

Deoxynivalenol was adsorbed only at $\mathrm{pH}$ value 3.0 by bentonite, diatomite and zeolite, respectively $(50 \%, 25 \%$ and $50 \%$, respectively).

Effect of electrolyte $\mathrm{pH}$ value on the binding of zearalenone was not much expressed (37\%-12.20\%).

None of the investigated natural mineral adsorbents bounded diacetoxyscirpenol.

The amount of adsorbed T-2 toxin ranged from 16.66 to $33.33 \%$.

In tested laboratory conditiond the best mineral adsorbent was shown to be diatomite because it binded in vitro five (AFL, OTA, DON, ZON and T-2) out of six tested mycotoxins.

The obtained results point out the need for activation or processing of natural mineral adsorbents, especially bentonite and zeolite, in order to increase the efficiency of adsorption of the wider spectrum of mycotoxins.

Nonetheless in vivo experiments are indispensable to proof the efficacy of investigated natural mineral adsorbenrs (BEN, DIA and ZEO).

\section{Acknowledgment}

The research was financed by the Ministry of Education and Science of the Republic of Serbia within the projects III-46005 and TR-31023. 


\title{
In vitro efikasnost prirodnih mineralnih adsorbenata mikotoksina
}

\author{
A. Bočarov-Stančić, M. Adamović, N. Salma, M. Bodroža-Solarov, J. Vučković, V. \\ Pantić
}

Rezime

$\mathrm{U}$ radu je prikazan in vitro model za evaluaciju sposobnosti za adsorpciju mikotoksina prirodnih mineralnih adsorbenata: bentonita, diatomita i zeolita pripremljenih u Institutu za tehnologiju nuklearnih i drugih mineralnih sirovina, Beograd. Testirano je ukupno šest mikotoksina: aflatoksin B1 (AFL), ohratoksin A (OTA), dezoksinivalenol (DON), zearalenon (ZON), diacetoksiscirpenol (DAS) i T-2 toksin. Za eksperimente adsorpcije su korišćeni sirovi ekstrakti mikotoksina, proizvedeni u Odeljenju mikrobiologije Bio-ekološkog centra, Zrenjanin.

Sposobnost za in vitro vezivanje mikotoksina je ocenjivana u elektrolitu $0,1 \mathrm{M} \mathrm{K}_{2} \mathrm{HPO}_{4}$ čija je pH vrednost podešena na 3,0 odnosno 6,9. Maseni odnos pojedinačnih mikotoksina i prirodnih mineralnih adsorbenasa je iznosio 1:5000. Eksperimentalne smeše su inkubirane tokom 1 sata na rotacionoj tresilici (185 $\mathrm{o} / \mathrm{min})$ i sobnoj temperaturi $\left(22-25^{\circ} \mathrm{C}\right)$. Nakon inkubacije vršena je ekstrakcija neadsorbovanih mikotoksina iz filtrata organskim rastvaračima i kvantifikacija istih metodom tankoslojne hromatografije.

Korišćenom metodom je konstatovano da su bentonit, diatomit i zeolit vezali više od $95 \%$ aplicirane količine AFL. U slučaju OTA samo je diatomit adsorbovao ovaj mikotoksin - indeks adsorpcije je bio 66,67\%. Vezivanje DON-a je konstatovano samo pri $\mathrm{pH}$ vrednosti 3,0 elektrolita. Njegov indeks adsorpcije je varirao od 25,00-50,00\% u zavisnosti od vrste mineralnog adsorbenta. Uticaj $\mathrm{pH}$ vrednosti elektrolita na vezivanje ZON-a nije bio izražen. Indeks adsorpcije ovog mikotoksina je iznosio od 12,20-37,00\%. Od trihotecena tipa A (DAS i T-2 toksin) bentonit, diatomit i zeolit su vezivali samo T-2 toksin. Količina adsorbovanog T-2 toksina je bila od 16,66 do 33,33\%. Dobijeni rezultati ukazuju na potrebu aktivacije ili oplemenjivanja prirodnih mineralnih adsorbenata, posebno bentonita $i$ zeolita, u cilju povećanja efikasnosti adsorpcije šireg spektra mikotoksina.

\section{References}

ADAMOVIĆ M., STOJANOVIĆ, M., GRUBIŠIĆ. M., KOVAČEVIĆ, D., MILOJKOVIĆ, J. (2009): Mogućnost korišćenja alumosilkatnih mineralnih sirovina u proizvodnji bezbedne hrane. XIV Savetovanje o biotehnologiji, Čačak, 27-28. mart 2009. Zbornik radova, 14, 367-376. 
ADAMOVIĆ M., TOMAŠEVIĆ-ČANOVIĆ, M., MILOŠEVIĆ S., DAKOVIĆ, A., LEMIĆ J. (2003): The contribution of mineral adsorbent in the improvement of animal performance, health and quality of animal products. Biotehnology in Animal Husbandry, 5-6, 383-395.

BOČAROV-STANČIĆ A., MAŠIĆ Z., GOLOŠIN B., BOKOROV M. (2000a): ispitivanje sposobnosti klinoptilolita (Minazel) za adsorpciju T-2 toksina. Acta Periodica Technologica, 31, A, 371-378.

BOČAROV-STANČIĆ A., TOMAŠEVIĆ-ČANOVIĆ M., DAKOVIĆ A. (2000b): The possibility of clinoptilolite (Minazel) use in prevention of trichothecene type A mycotoxicosis (in Serbian). Ecologica, 7, 2, 162-164.

BOČAROV-STANČIĆ A.S., JAĆEVIĆ V.M, RESANOVIĆ R.D., BIJELIĆ M.B. (2007): Optimisation of laboratory conditions for biosynthesis of type A trichothecenes. Zbornik Matice srpske za prirodne nauke - Proc. Nat. Sci., Matica Srpska, Novi Sad, 113, 35-44.

BOČAROV-STANČIĆ A.S., LEVIĆ T.J., DIMIĆ R.G., STANKOVIĆ Ž.S., SALMA M.N. (2009a): Investigation of toxigenic potential of fungal species by the use of simple screening method. Zbornik Matice srpske za prirodne nauke - Proc. Nat. Sci, Matica Srpska, Novi Sad, 116, 25-32.

BOČAROV-STANČIĆ A.S., LEVIĆ T.J., STANKOVIĆ Ž.S., STANIČIĆ M.M., BILEK O.S. (2009b): Dynamics of deoxynivalenol and zearalenone production by Fusarium graminearum under laboratory conditions. Zbornik Matice srpske za prirodne nauke - Proc. Nat. Sci, Matica Srpska, Novi Sad, 116, 15-24.

BOČAROV-STANČIĆ A.S., MILJKOVIĆ A., RESANOVIĆ R., NEČIĆ K., JAĆEVIĆ V., MIHALJČIĆ D. (2010): Ochratoxin A in vitro biosynthesis by Aspergillus ochraceous isolate. Zbornik Matice srpske za prirodne nauke - Proc. Nat. Sci, Matica Srpska, Novi Sad, 117, 69-77.

BUENO D.J., DI MARCO L., OLIVER G., BARDÓN A. (2005): In vitro binding of zearalenone to different adsorbens. J. Food Prot., 68(3), 613-615.

CARSON M.S., SMITH T.K. (1983): Role of bentonite in prevencion of T-2 toxicosis in rats. J. Anim. Sci., 57, 6, 1498-1506.

DAKOVIC A., TOMASEVIC-CANOVIC M., DONDUR V., STOJSIC D., ROTTINGHAUS G. (2001): 32-O-04- In vitro adsorption of zearalenone by octadecyldimethylbenzyl ammonium-excanged clinoptilolite-heulandite tuff and bentonite. Studies in Surface Science and Catalysis, 135, 171.

DEVEGOWDA C., ARAVIND K.L. (2002): Mycotoxins: Economic risk and control. Grain and Feed Milling Technology, April-May, 13-16.

DÖLL S., DÄNICKE S., VALENTA H., FLACHOWSKY G. (2004): In vitro studies on the evaluation of mycotoxin detoxifying agents for their efficacy on deoxynivalenol and zearalenone. Arch. Anim. Nutr., 58, 4, 311-324.

ĐORĐEVIĆ N., GRUBIĆ G., ADAMOVIĆ M., STOJANOVIĆ B., SIMIĆ A. (2006): Uticaj dodavanja minazela plus na kvalitet silaža oplemenjenih 
neorganskim i organskim azotom. Biotechnology in Animal Husbandry, 22, spec. issue, 549-559.

HUWIG A., FREIMUND S., KÄPPELI O., DUTLER H. (2001): Mycotoxin detoxication od animal feed in animal feed adsorbents. Toxicology Letters, 122, 179-188.

JAĆEVIĆ V., BOČAROV-STANČIĆ A., RESANOVIĆ R. ĐORĐEVIĆ S., JELIĆ K., MILOSAVLJEVIĆ I. (2007): Modified zeolite uses for prevention of subacute T-2 toxicosis: Effects on the lymphoid tissues. International Congress of Toxicology, Montreal, Canada, 15-19 July 2007. Abstracts.

KOLLOSOVA A., STROKA J., BREIDBACH A., KROEGER K., ABBROSIO M., BOUTEN K., ULBERTH F. (2009): Evaluation of the Effect of Mycotoxin Binders in animal feed on the Analytical performance on standardised methods for Determination of Mycotoxins in Feed. EUR 23997 ENJRC Scientific and Technical Reports, 1-46.

MANAFI M., NARAYANASWAMY H.D., PIRANY N. (2009): In vitro binding ability of mycotoxin binder in commercial broiler feed. African J. Agricultural Research, 4, 2, 141-143.

NEŠIĆ V.D., OSTOJIN M.V., NEŠIĆ K.D., RESANOVIĆ R.D. (2007): Evaluation of efficacy of different feed aditives to adsorb T-2 toxin in vitro. Zbornik Matice srpske za prirodne nauke - Proc. Nat. Sci., Matica srpska, Novi Sad, 116, 55-59.

RUKMINI C., BHAT R.V. (1978): Occurrence of T-2 toxin in Fusarium-infested sorghum from India. J. Agric. Food Chem., 26, 647-649.

SABATER-VILAR M., MALEKINEJAD H., SELMAN M.H.J., VAN DER DOELEN M., FINK-GREMMELS J. (2004): In vitro assesment of adsorbents aiming to prevent deoxynivalenol and zearalenone mycotoxicoses. Mycopathologia, 163, 2, 81-90.

STOJANOVIĆ A.I., DAKOVIĆ A.S., MATIJAŠEVIĆ S.D., ROTTINGHAUS G.E., SEKULIĆ Ž.T., STANIĆ T.T. (2008): Adsorpcija T-2 toksina mineralnim adsorbensima. Hem. ind., 62, 2, 59-68.

STOJANOVIĆ B., GRUBIĆ G., ĐORĐEVIĆ N., ADAMOVIĆ M. (2008): Značaj peletiranja i korišćenja Na-bentonita u proizvodnji smeša za ishranu goveda. Biotechnology in Animal Husbandry, 24, spec. issue, 435-444.

STOJŠIĆ D., STOJKOVIĆ M., DAKOVIĆ A., ADAMOVIĆ M., TOMAŠEVIĆČANOVIĆ M. (2004): Efficacy of organozeolite to ameliorate the toxic effects of zearalenone in lambs. Acta Veterinaria, 54, 1, 53-62.

THE OFFICIAL GAZETTE OF SFRJ (1978): Regulations on sampling methods and methods of physical, chemical and microbiological analysis of fodder. Issue $15,865-861$.

THIMM N., SCHWAIGHOFER B., OTTNER F., FRÖSCHL H., GREIFENENDER S., BINDER E.M. (2001): Adsorption of mycotoxins. Mycotoxin Research, 17, 2, 219-223. 
TOMAŠEVIĆ-ČANOVIĆ M., DAKOVIĆ A., VUKIĆEVIĆ O., ADAMOVIĆ M., BOČAROV-STANČIĆ A., ROTTINGHAUS G.(2001): Površinski modifikovan klinoptilolit-novi efikasni adsorbent mikotoksina. XV Savetovanje agronoma, veterinara i tehnologa, Institut PKB Agroekonomik, Beograd, 7, 1, 291-297.

VIĆENTIJEVIĆ M., MITROVIĆ R., VITOROVIĆ G. (2006): Efikasnost klinoptilolita posle višekratne alimentarne kontaminacije fazana ${ }^{137} \mathrm{Cs}$. Biotechnology in Animal Husbandry, 22, 3-4, 105-114.

ŽIVKOVIĆ C., PAUNOVIĆ A., MILOVANOVIĆ M. (2006): Valorizacija prirodnih nemetaličnih mineralnih sirovina $u$ melioraciji $i$ fertilizaciji poljoprivrednog zemljišta kao prve i osnovne pretpostavke $u$ zasnivanju organske poljoprivredne proizvodnje u Republici Srbiji. U monografiji: Prirodne mineralne sirovine $i$ mogućnosti njihove upotrebe $u$ poljoprivrednoj proizvodnji i prehrambenoj industriji, Savez poljoprivrednih inženjera i tehničara Srbije, Beograd, 9-35.

WHITLOW L.W. (2006): Evaluation of mycotoxin binders. $4^{\text {th }}$ Mid-Atlantic Nutrition Conference (Zimmerman, N.G. ed.), Proceedings, 132-143. 